\title{
Методика оцінювання ефективності функціонування системи підтримки аварійно-відновлювальних робіт, пов'язаних з надзвичайними ситуаціями воєнного характеру
}

\author{
Володимир Коцюруба * А; Світлана Ганненко А \\ А Національний університет оборони України імені Івана Черняховського, пр-кт Повітрофлотський, 28, м. Київ, 03049, Україна
}

Received: October 05, 2020 | Revised: October 27, 2020 | Accepted: October 31, 2020

DOI: $10.33445 /$ sds.2020.10.5.10

\begin{abstract}
Анотація
В статті розглянуто удосконалену методику оцінювання ефективності функціонування системи підтримки аварійно-відновлювальних робіт, пов'язаних 3 надзвичайними ситуаціями воєнного характеру.

На сьогоднішній час для оцінювання ефективності застосування різнорідних сил та засобів цивільного захисту застосовуються, в основному, евристичний та дослідно-теоретичний методи, які базуються на використанні деяких імовірнісних характеристик, розрахованих за допомогою аналітичних залежностей.

Вірний вибір показників та критерію $€$ вирішальним, важливим і складним етапом під час удосконалення методики оцінювання ефективності функціонування системи підтримки аварійно-відновлювальних робіт, пов'язаних з надзвичайними ситуаціями. Вони залежать, перш за все, від змісту аварійно-відновлювальних робіт, наявність та склад сил та засобів, що залучаються до процесів підтримки аварійно-відновлювальних робіт, зокрема до забезпечення режим припинення вогню та гуманітарного розмінування, а також фізикогеографічних, кліматичних характеристик та техногенного навантаження операційного району.

Аналіз особливостей функціонування системи підтримки аварійно-відновлювальних робіт в умовах воєнного часу свідчить про необхідність розгляду питання щодо удосконалення методики оцінювання ефективності функціонування системи підтримки аварійновідновлювальних робіт, яка б врахувала особливості появи і накопичення обсягів завдань з розмінування, які потребують своєчасного вирішення.
\end{abstract}

Ключові слова: система підтримки, аварійно-відновлювальні роботи, надзвичайні ситуації, потенційно-небезпечні об'єкти, гуманітарне розмінування.

\section{Постановка проблеми}

Досвід локальних війн та збройних конфліктів дає підстави вважати, що з початком збройного протистояння будуть зруйнування (як навмисні, так і супутні) промислових, енергетичних, транспортних та військових об'єктів. У кожному випадку їх масштаби будуть обумовлені геостратегічним положенням району конфлікту, оперативнотактичною доцільністю їх зруйнування.

Сучасним операціям притаманні певні риси, з яких, одними з основних $€$ випередження противника та досягнення оперативної раптовості за рахунок початку операцій обмеженим складом сил і засобів до завершення оперативного розгортання всього угруповання та ведення бойових дій у густонаселених районах місцевості (населених пунктах), що характерно для стабілізаційної операції.

Отже особливостями будь-яких операцій (бойових дій) $\epsilon$ те, що під час їх ведення виникають надзвичайні ситуації воєнного

\footnotetext{
* Corresponding author: д.т.н., професор, заслужений винахідник України, професор кафедри, e-mail: kotcuru@ukr.net
} 
характеру, як результат супутнього або навмисного руйнування об'єктів інфраструктури з порушенням міжнародного гуманітарного права [1]. Проведення аварійновідновлювальних робіт супроводжується певними процесами підтримки, до яких належить забезпечення режиму припинення вогню та гуманітарного розмінування [2-5].

Збройна агресія і порушення територіальної цілісності України, нарощування військового потенціалу Російської Федерації у безпосередній близькості до державного кордону України, а також наявність на території України потенційно-небезпечних об'єктів викликає особливе занепокоєння стосовно спланованого або супутнього їх зруйнування у ході ведення операцій військ (сил).

\section{Аналіз останніх досліджень та публікацій}

Аналіз останніх наукових досліджень і публікацій [6-9] свідчить про те, що дослідженню заходів протимінної діяльності під час ведення бойових дій присвячена низка робіт попередників, зокрема Мосова С.П., Куртсеітова Т.Л., Хоміка М.М. та інших, які в свій час зробили вагомий внесок у розвиток теорії військової науки. Аналізуючи ï наукові дослідження можна зробити висновок про те, що в них частково не враховані нові чинники, які в сучасних умовах гібридної війни значно впливають на ефективність функціонування протимінної діяльності. Але, безумовно, наявні дослідження можуть і мають бути обрані за основу для подальшого їх удосконалення.

Результати зазначених досліджень можуть бути використані під час залучення та участі сил, засобів та ресурсів ЗС України у ліквідації наслідків надзвичайних ситуацій воєнного характеру та здійснення управління техногенною безпекою за рахунок мінімізації ризику задіяного особового складу.

\section{Постановка завдання}

Методики оцінювання ефективності функціонування вказаної системи в умовах інтенсивного зруйнування об'єктів інфраструктури не у повному обсязі враховують імовірнісний характер процесів аварійно-відновлювальних робіт (далі - АВР) в умовах постійного вогневого впливу ворогуючих сторін, їх залежність від якості забезпечуючих заходів, можливості щодо режиму припинення вогню та гуманітарного розмінування та ризик не виконання заходів. Враховуючи зазначене, виникає нагальна необхідність у вдосконаленні існуючих методик $[10,11]$.

Дані обставини дають можливість сформулювати протиріччя у практиці, між існуючим рівнем ефективності процесів підтримки АВР в умовах інтенсифікації зруйнування об'єктів критичної інфраструктури і необхідним, вирішення якого забезпечить контроль імовірного рівня ризику збільшення соціального напруження, втрати здоров'я цивільного населення в районах ведення бойових дій та підтримання його у межах допустимого.

При цьому, в теоретичній галузі наявні протиріччя полягають в недосконалості науково-методичного апарату оцінювання ефективності функціонування системи підтримки аварійно-відновлювальних робіт (далі - СПАВР), пов'язаних з надзвичайними ситуаціями (далі - НC), як наслідок ведення бойових дій, та потребою врахування суттєвих чинників, що призводить до зниження достовірності одержаних результатів.

Вищезазначені обставини та актуальність теми статті вимагають вирішення наукового завдання, сутність якого полягає в удосконаленні методики оцінювання ефективності функціонування системи підтримки аварійно-відновлювальних робіт, пов'язаних з надзвичайними ситуаціями. 


\section{Виклад основного матеріалу}

Для удосконалення методики оцінювання ефективності функціонування системи підтримки аварійно-відновлювальних робіт на початку проведено визначення показників та критерію оцінювання ефективності процесів підтримки АВР.

На сьогоднішній час для оцінювання ефективності застосування різнорідних сил та засобів цивільного захисту застосовуються, в основному, евристичний та досліднотеоретичний методи, які базуються на використанні деяких імовірнісних характеристик, розрахованих за допомогою аналітичних залежностей [7].

Вірний вибір показників та критерію [10, 11] $€$ вирішальним, важливим і складним етапом під час удосконалення методики оцінювання ефективності функціонування СПАВР, пов'язаних з НС. Вони залежать, перш за все, від змісту АВР, наявність та склад сил та засобів, що залучаються до процесів підтримки АВР, зокрема до забезпечення режиму припинення вогню та гуманітарного розмінування, а також фізико-географічних, кліматичних характеристик та техногенного навантаження операційного району.

В якості основного показника в роботі обрано рівень успішності АВР внаслідок функціонування СПАВР:

$$
Q_{p}(t)=f\left(F_{j}(t) ; P_{i j}\right),
$$

де $\mathrm{F}_{j}(t)$ - імовірність перебування системи у ј-му стані;

$\mathrm{P}_{i j}$ - імовірність переходу системи з $i$-го стану до $j$-го.

Критерієм оцінювання ефективності функціонування СПАВР, пов'язаних з НС, та відповідності меті АВР обрано правило прийняття рішення по придатності:

$$
Q_{p}(t) \geq Q_{\Pi}
$$

де $\mathrm{Q}_{n}$ - мінімально допустиме значення основного показника ефективності функціонування СПАВР.

У результаті дослідження були обрані та обґрунтовані показники та критерій оцінювання ефективності функціонування
СПАВР.

Структурно-логічна схема методики оцінювання ефективності функціонування системи підтримки аварійно-відновлювальних робіт наведена на малюнку 1.

Послідовність проведення розрахунків наступна.

у блоці 1 здійснюють введення вхідних даних, до яких відносять відомості щодо ендогенних та екзогенних факторів, апріорні чисельні значення часткових показників тощо.

Блок 2 - формують повну множину варіантів альтернатив функціонування СПАВР із врахуванням множини процесів підтримки АВР та пріоритетності об'єктів критичної інфраструктури. В роботі для дослідження обрано наступні варіанти альтернатив функціонування СПАВР: A1 - ситуативноорієнтований підхід; А2 - розгалужений або розосереджений підхід; АЗ - послідовнооб'єктовий підхід; А4 - адаптивний підхід.

Моделювання процесів підтримки здійснюється у блоці 3 , де на підґрунті застосування розробленої імітаційноаналітичної моделі функціонування СПАВР та сертифікованого середовища введення, відображення та моделювання епізодів бойових дій JCATS визначають чисельні значення основного показника ефективності процесів підтримки АВР $Q_{p}(t)$, який характеризує ймовірність успішного виконання АВР на об'єктах критичної інфраструктури згідно із обраними варіантами надзвичайних ситуацій воєнного характеру (наприклад: відновлення об'єктів водопостачання на пріоритетній ділянці; ремонт виведеної з ладу лінії електропередач в межах лінії зіткнення сторін; відновлення дамби шламонакопичувача за межами лінії зіткнення сторін в зоні досяжності вогневих засобів противника).

Блок $4 \epsilon$ оператором циклічного перебору всіх можливих варіантів альтернатив функціонування СПАВР.

Після завершення моделювання за всіма 


\begin{tabular}{|c|c|}
\hline ожливими варіантами альт & укупності пре \\
\hline ункціонування СПАВР у блоці 5 , & 9-12 у сукупності предс \\
\hline оють значення основного по & новану в роботі часткову м \\
\hline фективності функціонування СПАВР, які & $\begin{array}{l}\text { оцінювання та обґрунтування рац } \\
\text { параметрів перспективної сп }\end{array}$ \\
\hline u & ґрунтується на комплексному вик \\
\hline У разі невиконання умови критерію & методів експерт \\
\hline поці 7 прийма & \\
\hline едоцільність обирання вказаного варіанту & $\Pi p$ \\
\hline 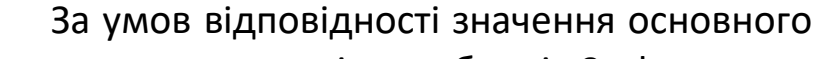 & ван \\
\hline оказника критерію у блоці & \\
\hline
\end{tabular}
кортеж доцільних для подальшого

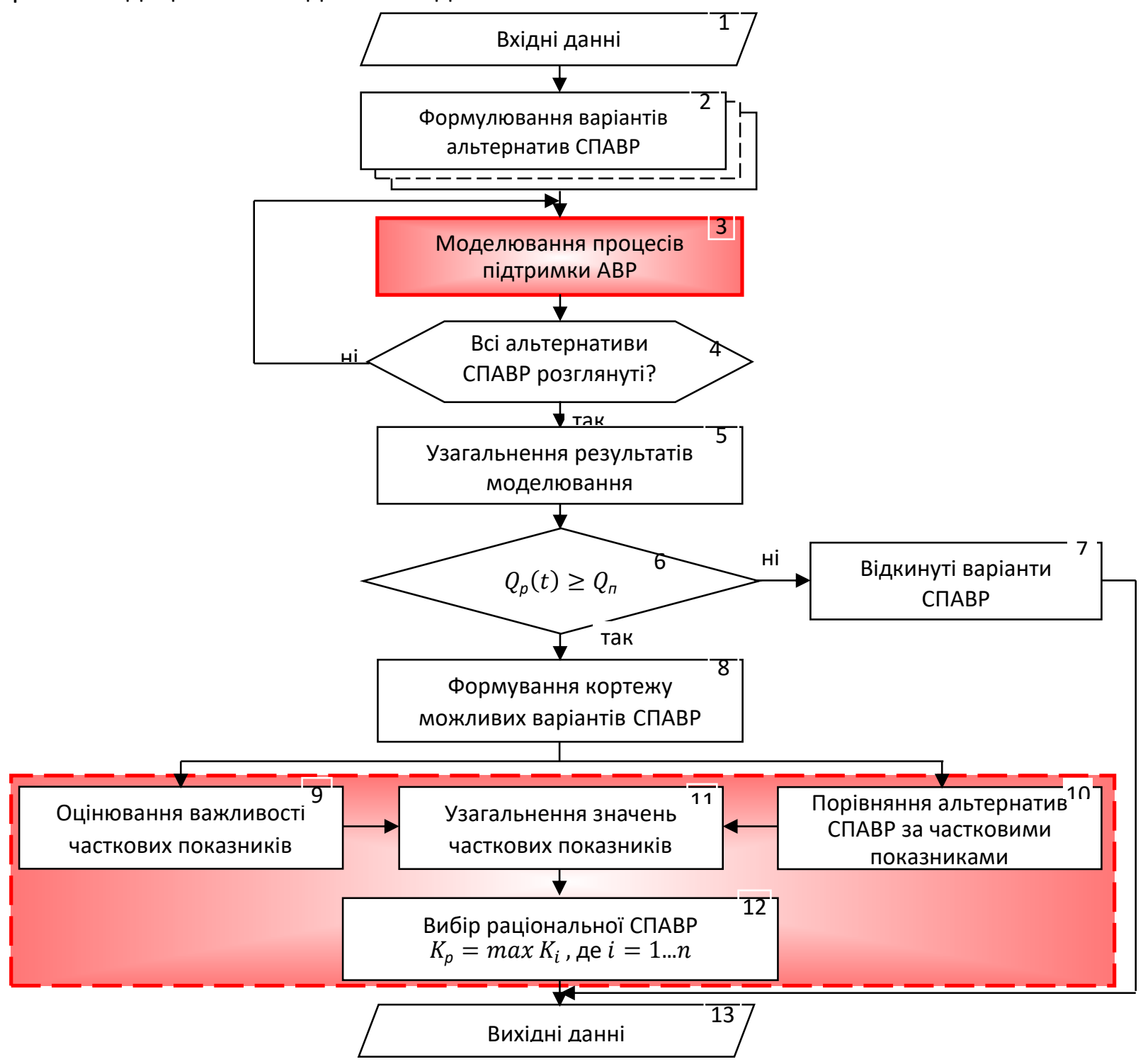

Малюнок 1 - Структурно-логічна схема методики оцінювання ефективності функціонування СПАВР

у блоці 10 відбувається порівняння чисельнихзначень.

альтернатив СПАВР за частковими Узагальнений показник вирішення
показниками шляхом нормування їх багатокритеріальної задачі оптимізації на 
множині цілей/якостей визначають у блоці 11 за формулою

$$
Q_{i}=\sum_{j=1}^{J} \beta_{j} q_{i j}
$$

де $\beta_{\mathrm{j}}-$ коефіцієнт вагомості $j$-ї властивості (характеристики);

$q_{i j}$ - відносний одиничний показник $j$-ї властивості і-го варіанту альтернативи СПАВР.

Для приведення до одиниці одержані значення показника (3) нормують:

$$
K_{j}=\frac{Q_{j}}{\max Q_{j}}
$$

Раціональний варіант СПАВР обирають у блоці 12 із використанням оптимізаційного критерію (5)

\section{Висновки}

Отже, в статті представлено удосконалену методику оцінювання ефективності процесів підтримки аварійно-відновлювальних робіт, пов'язаних з надзвичайними ситуаціями, яка на відміну від існуючих, додатково містить блоки формування варіантів альтернатив структури, моделювання функціонування та обгрунтування раціональних параметрів організаційно-технічної системи підтримки аварійно-відновлювальних робіт.

\section{Список використаних джерел}

1. Кодекс цивільного захисту України : Закон України від 02.10.2012 р. № 5403-VI. Дата оновлення: 01.01.2019. URL: https://zakon. rada.gov.ua/laws/show/5403-17\#n1517.

2. Про особливості державної політики із забезпечення державного суверенітету України на тимчасово окупованих територіях у Донецькій та Луганській областях: Закон України № 2268-VIII від 18.01.2018, [Електронний ресурс] // Відомості Верховної Ради України (ВВР), 2018. URL: https://zakon.rada.gov.ua/laws/ show/2268-19\#Text.

3. Про протимінну діяльність в Україні: Закон України № 2642-VIII від 06.12.2018, [Електронний ресурс] // Відомості Верховної Ради України (BBP), 2018. URL: https://zakon.rada.gov.ua/laws/show/2642-

$$
K_{p}=\max K_{i} \text {, де } i=1 \ldots n .
$$

Таким чином, обрана сукупність показників дозволить доволі повно врахувати різнорідну множину цілей або якостей процесів функціонування організаційно-технічної СПАВР. Для розв'язання багатокритеріальної задачі оцінювання та вибору раціонального варіанту серед можливих альтернатив СПАВР потрібно удосконалити існуючі методики оцінювання ефективності функціонування систем даного типу.

На підґрунті результатів проведених розрахунків обгрунтовуються рекомендації щодо раціональної структури та параметрів перспективної СПАВР, які узагальнюються у блоці 13.

Застосування запропонованої методики дозволило виконати умову, щодо забезпечення виконання бойових завдань воєнного характеру та провести оцінювання функціонування системи підтримки аварійновідновлювальних робіт, пов'язаних 3 надзвичайними ситуаціями воєнного характеру за рахунок підвищення ефективності ii функціонування в умовах зараження небезпечними хімічними речовинами.

\section{9\#Text.}

4. Про затвердження типових положень про функціональну і територіальну підсистеми єдиної державної системи цивільного захисту: Постанова КМ України від 11.03.2015 № 101. Дата оновлення: 27.03.2015. URL: https://zakon.rada.gov.ua/ laws/card/101-2015-\%D0\%BF.

5. Про затвердження Положення про функціональну підсистему запобігання надзвичайним ситуаціям і ліквідації їх наслідків у підпорядкованих організаціях, на підвідомчих об'єктах і територіях Міністерства оборони України єдиної державної системи цивільного захисту : Наказ Міністерства оборони України від 08.05.2019 № 220. Київ, 2019. 15 с.

6. Куртсеітов Т. Л., Мосов С. П., 
Трембовецький М.П., Ясько В.А. Мінна зброя у фокусі сучасних війн і збройних конфліктів: зб. наук. праць Центру воєнностратегічних досліджень НУОУ №2(69). 2020. DOI: 10.33099/2304-2745/2020-269/116-121.

7. Хомік М. М. Закономірності застосування військ (сил) Збройних Сил України та інших військових формувань під час ліквідації наслідків надзвичайних ситуацій. Техногенно-екологічна безпека та цивільний захист. Київ : ДУ ІГНС НАНУ, 2017. № 2 (6). С. 67-75.

8. Хомік М. М. Принципи застосування військ (сил) Збройних Сил України та інших військових формувань під час надзвичайних ситуацій. Техногенно- екологічна безпека та цивільний захист. Київ : ДУ ІГНС НАНУ, 2017. № 3 (9). С. 85-92.

9. Бочаров О.А. Алгоритмизация процессов в деятельности по разминированию как основа создания эффективных стандартных процедур действий // Науковий вісник УкрНДІПБ. - 2007. - № 2 (16). - С. 202-205.

10. Юрков Б. Н. Исследование операций / Юрков Б. Н. - М.: ВИА, 1990. 528 с.

11. Блекот О. М., Романюк В. П., Нікітін А. А., Коцюруба В.І. Методика оцінювання обстановки у надзвичайних ситуаціях техногенного та природного характеру : навч.-метод. посіб. Київ : НУОУ, 2018. $124 \mathrm{c}$.

\title{
Методика оценки эффективности функционирования системы поддержки аварийно-восстановительных работ, связанных с чрезвычайными ситуациями военного характера
}

\author{
Владимир Коцюруба * А; Светлана Ганненко А \\ *Corresponding author: д.т.н., професор, заслуженный изобретатель Украины, профессор кафедры, e-mail: kotcuru@ukr.net \\ А Национальный университет обороны Украины имени Ивана Черняховского, пр-кт Воздухофлотский, 28, г. Киев, 03049, Украина
}

\section{Аннотация}

В статье рассмотрено усовершенствованная методика оценки эффективности функционирования системы поддержки аварийно-восстановительных работ, связанных с чрезвычайными ситуациями военного характера.

На сегодняшнее время для оценки эффективности применения разнородных сил и средств гражданской защиты применяются, в основном, эвристический и опытно-теоретический методы, основанные на использовании некоторых вероятностных характеристик, рассчитанных с помощью аналитических зависимостей.

Правильный выбор показателей и критерия является решающим, важным и сложным этапом при усовершенствовании методики оценки эффективности функционирования системы поддержки аварийно-восстановительных работ, связанных с чрезвычайными ситуациями. Они зависят, прежде всего, от содержания аварийно-восстановительных работ, наличие и состав сил и средств, привлекаемых к процессам поддержки аварийновосстановительных работ, в частности к обеспечению режим прекращения огня и гуманитарного разминирования, а также физико-географических, климатических характеристик и техногенной нагрузки операционного района.

Анализ особенностей функционирования системы поддержки аварийновосстановительных работ в условиях военного времени свидетельствует о необходимости рассмотрения вопроса по совершенствованию методики оценки эффективности функционирования системы поддержки аварийно-восстановительных работ, которая учла особенности появления и накопления объемов задач по разминированию, требующих своевременного решения. 
Ключевые слова: система поддержки, аварийно-восстановительные работы, чрезвычайные ситуации, потенциально опасные объекты, гуманитарное разминирование.

\title{
Methods for assessing the effectiveness of the support system for emergency recovery work related to military emergencies
}

\author{
Volodymyr Kotsiuruba * A; Svitlana Hannenko A
}

"Corresponding author: Doctor of Technical Sciences, Professor, Honored Inventor of Ukraine, Professor of the Department, e-mail: kotcuru@ukr.net

A National Defence University of Ukraine named after Ivan Cherniakhovskyi, 28, Povitroflotskyi Ave, Kyiv, 03049, Ukraine

\begin{abstract}
The article considers an improved method of assessing the effectiveness of the system of support for emergency recovery work related to military emergencies.

At present, heuristic and research-theoretical methods are used to assess the effectiveness of the use of heterogeneous forces and means of civil protection, which are based on the use of some probabilistic characteristics calculated using analytical dependences.

The correct choice of indicators and criteria is a crucial, important and difficult step in improving the methodology for assessing the effectiveness of the system of support for emergency recovery work related to emergencies. They depend, first of all, on the content of emergency recovery works, the availability and composition of forces and means involved in the processes of support of emergency recovery works, in particular to ensure the ceasefire and humanitarian demining, as well as physical-geographical, climatic characteristics and technogenic load of the operating area.

Analysis of the features of the emergency support system in wartime indicates the need to consider improving the methodology for assessing the effectiveness of the emergency support system, which would take into account the peculiarities of the emergence and accumulation of demining tasks that need to be addressed in a timely manner.
\end{abstract}

Keywords: support system, emergency recovery work, emergencies, potentially dangerous objects, humanitarian demining.

\section{References}

1. Kodeks tsyvil'noho zakhystu Ukrayiny : Zakon Ukrayiny vid 02.10.2012 r. № 5403-VI. Data onovlennya: 01.01.2019. Available from : https://zakon. rada.gov.ua/laws/show/5403$17 \#$ 1517.

2. Pro osoblyvosti derzhavnoyi polityky iz zabezpechennya derzhavnoho suverenitetu Ukrayiny na tymchasovo okupovanykh terytoriyakh u Donets'kiy ta Luhans'kiy oblastyakh: Zakon Ukrayiny № 2268-VIII vid 18.01.2018, [Elektronnyy resurs] // Vidomosti Verkhovnoyi Rady Ukrayiny (VVR), 2018. Available from : https://zakon. rada.gov.ua/laws/show/2268-19\#Text.

3. Pro protyminnu diyal'nist' v Ukrayini: Zakon Ukrayiny № 2642-VIII vid 06.12.2018, [Elektronnyy resurs] //Vidomosti Verkhovnoyi Rady Ukrayiny (VVR), 2018.
Available from : https://zakon.rada.gov.ua/ laws/show/2642-19\#Text.

4. Pro zatverdzhennya typovykh polozhen' pro funktsional'nu i terytorial'nu pidsystemy yedynoyi derzhavnoyi systemy tsyvil'noho zakhystu: Postanova KM Ukrayiny vid 11.03.2015 № 101. Data onovlennya: 27.03.2015. Available from : https://zakon. rada.gov.ua/laws/card/101-2015-\%D0\%BF.

5. Pro zatverdzhennya Polozhennya pro funktsional'nu pidsystemu zapobihannya nadzvychaynym sytuatsiyam i likvidatsiyi yikh naslidkiv u pidporyadkovanykh orhanizatsiyakh, na pidvidomchykh ob'yektakh i terytoriyakh Ministerstva oborony Ukrayiny yedynoyi derzhavnoyi systemy tsyvil'noho zakhystu : Nakaz Ministerstva oborony Ukrayiny vid 
08.05.2019 № 220. Kyyiv, 2019. 15 s.

6. Kurtseitov T. L., Mosov S. P., Trembovets'kyy M.P., Yas'ko V.A. Minna zbroya u fokusi suchasnykh viyn i zbroynykh konfliktiv: $z b$. nauk. prats' Tsentru voyenno-stratehichnykh doslidzhen' NUOU №2(69). 2020. DOI: 10.33099/2304-2745/2020-2-69/116-121.

7. Khomik M. M. Zakonomirnosti zastosuvannya viys'k (syl) Zbroynykh Syl Ukrayiny ta inshykh viys'kovykh formuvan' pid chas likvidatsiyi naslidkiv nadzvychaynykh sytuatsiy. Tekhnohenno-ekolohichna bezpeka ta tsyvil'nyy zakhyst. Kyiv : DU IHNS NANU, 2017. № 2 (6). S. 67-75.

8. Khomik M. M. Pryntsypy zastosuvannya viys'k (syl) Zbroynykh Syl Ukrayiny ta inshykh viys'kovykh formuvan' pid chas nadzvychaynykh sytuatsiy. Tekhnohenno- ekolohichna bezpeka ta tsyvil'nyy zakhyst. Kyyiv : DU IHNS NANU, 2017. № 3 (9). S. 8592.

9. Bocharov O.A. Alhorytmyzatsyya protsessov v deyatel'nosty po razmynyrovanyyu kak osnova sozdanyya éffektyvnykh standartnykh protsedur deystvyy // Naukovyy visnyk UkrNDIPB. - 2007. - № 2 (16). - S. 202-205.

10. Yurkov B. N. Yssledovanye operatsyy / Yurkov B. N. - M.: VYA, $1990.528 \mathrm{~s}$.

11. Blekot O. M., Romanyuk V. P., Nikitin A. A., Kotsyuruba V. I. Metodyka otsinyuvannya obstanovky u nadzvychaynykh sytuatsiyakh tekhnohennoho ta pryrodnoho kharakteru: navch.-metod. posib. Kyyiv : NUOU, 2018. $124 \mathrm{~s}$. 